https://doi.org/10.22364/hssl.28.2.05

\title{
E-COMMERCE IN NIGERIA: BENEFITS AND CHALLENGES
}

\author{
Ugo Chuks Okolie \\ MA
}

\section{Awulika Happiness Ojomo \\ B.Ed.}

\begin{abstract}
E-commerce activities in Nigeria are rapidly growing as a result of vast improvements in telecommunication services. And e-banking is one area of e-commerce that has proven successful in Nigeria. The growth of internet users from year 2000 to 2019 is sporadic as it recorded $73 \%$ growth rates. This study explores the benefits of e-commerce and the challenges of e-commerce that inhibit its successful operation in Nigeria. Survey research was adopted for this study. The questionnaire was designed and administered randomly to 1200 respondents. Collected data were analysed using Statistical Package for Social Science (SPSS). The findings indicate that the major benefits of e-commerce adoption in Nigeria are increased sales, competitive advantage, customer loyalty, increased automation of processes, extended application of new technology, better knowledge management, and enhanced well-being and education of customer. The key challenges identified in the Nigerian context include power outages and frequent power interruption, insecurity, technology cost, lack of trust in web retailers, software compatibility, and acquisition of IT skilled personnel. The study recommends, among other issues, the need for adequate publicity on e-commerce with emphasis on e-shopping, e-banking, and e-business.
\end{abstract}

Keywords: Nigeria, e-commerce, benefits, challenges, Internet

\section{Introduction}

E-commerce is the use of the internet for marketing, identification, payment and delivery of goods and services. Through the e-commerce technology, the internet has revolutionised the mode of business transactions by providing customers with the ability to bank, invest, purchase, distribute, communicate, explore and research from virtually anywhere, anytime where there is internet access (Anup, 1997; Ayo, Adewoye \& Oni, 2011). Economic offers a level playing ground for large businesses, as well as small and medium-scale enterprises (SMEs) to operate in the global marketplace, and for regional businesses and communities 
to participate in social, economic and cultural networks seamlessly across international boundaries (Mary-Anne, 1988). However, with the paradigm shift in the mode of operation occasioned by the advent of the internet, global corporations now operate with much consistency and at reduced cost of transactions as if the entire world were a single entity. In Nigeria, the internet business is taking on a serious dimension in the country especially within the more commercial states of the nation.

A lot of start-ups are springing up within the cyber space and each one is targeting the over 40 million internet users in the country. At present, Jumia and Konga are the 'Beasts' of e-commerce in Nigeria (Babatunde, 2013). In the business-to-business world, buyers previously faced a number of obstacles to getting the best deal: suppliers were distant, research time was scarce, and intermediaries controlled most of the information. Presently, Web-based companies are becoming the new intermediaries, the conduit between producers and buyers. The benefits of e-commerce include customer loyalty, the speed of access, reduced costs of operation, transformation of traditional market chain, acquisition of a niche market, business efficiency, increased automation of process, retained and expanded customer base, enhancing well-being and education of customers. However, the growth of e-commerce in Nigeria is affected by accessibility, privacy and confidentiality, establishing cost, data security, network reliability, credit card threat, citizens' income and education, authenticity, cyber crime, poor technological infrastructures and fear of inadequate security in online environments (Ayo, 2011). This study therefore aims at two major objectives, first to examine to benefits of e-commerce in Nigeria and second its challenges. Also, the study recommends among others the need for adequate publicity on e-commerce with emphasis on e-shopping, e-banking and e-business.

\section{Conceptual Framework}

Till (1998) affirms that e-economic covers any form of business or administrative transaction or information exchange that is executed using any information and communications technology (ICT). The Organization for Economic Cooperation and Development (OECD) defines e-economic as a new way of conducting business, qualifying it as business occurring over network which use non-proprietary protocols that are established through an open standard setting process such as the internet. According to Kinder (2007), e-economic refers to as commercially purposive systems or processes of search assessment and transactions, including post transaction interactions, enabled and supported by information and communications technologies. Andam (2003) sees e-economics as the use of electronic 
communications and digital information processing technology in business transaction to create, transform, and redefine relationships for value creation between or among organisations, and between organisations and individuals. In the words of Lawal and Ogbu (20015), e-economics involves conducting business using modern communication instrument such as telephone, fax, e-payment, money transfer systems, e-data inter-change and the internet.

According to Kuliya (2015), e-economic encompass marketing and selling over the internet (e-retailing), business-to-business electronic data inter change (EDI), conducting research and seeking information, emailing and computer faxing, internal information networks for employees, and ensuring the security of online transactions and information transfers. Business types included among the case studies are business-to-customer (B2C), business-to-business (B2B), online or virtual business, storefront (bricks and mortar) businesses with Internet sales or purchases, and home based businesses. Chaitthralaxmi and Shruthi (2016) asserts that e-economic is a concept covering any form of business transaction or information exchange executed using information and communication technology between companies and public administration. In a nutshell, e-economics may, however, be simply defined as the buying and selling of products and services via telecommunication networks.

The term e-commerce usually is used interchangeably with e-business but they are distinct concepts. According to Andam (2003), in e-economics, information and communication technology (ICT) is used in inter-business or inter-organisational transactions (transactions between and among organisations) and in business-to-consumer transactions (transactions between firms/organisations and individuals). In e-business, on the other hand, information and communication technology (ICT) is used to enhance one's business. It includes any process that a business organisation (either for-profit, government or non-profit entity) conducts over a computer-mediated network. A more comprehensive definition of e-business is "the transformation of an organization's processes to deliver additional customer value through the application of technologies, philosophies and computing paradigm of the new economy" (Ibrahim \& Abubakar, 2015:2). In applauding Jumia.com for organising the first e-economics conference in Nigeria, Omobola (2012) noted that the ICT industry had become the primary driver of growth in the Nigeria economy, and commended the likes of Jumia.com who have pioneered online retail trade in Nigeria. She posits further, that the e-economics industry had continued to receive a boost in Nigeria, which has shown that it is possible for Nigerians to run such a business model within our shores. She concluded that e-economics, if well harnessed will drive local 
content development in the country and urged enterprises like Jumia.com to provide the platform for start-up, small and medium enterprises to leverage and grow their businesses.

Generally, e-economics can be broken down into two branches. These are: e-merchandise and e-finance:

E-merchandise: Selling goods and services electronically and moving items through distribution channels, for example, through internet shopping for groceries, hardware, gifts tickets, music, cloths, book, etc.

E-finance: Debit cards, smart cards, banking machines, telephone and internet banking, financial service and mortgages online, etc.

Moreover, a company's Web page can make it easy or hard for the customer to get the information leading to a purchase. As some have learned the hard way, it is not enough to simply take images that are successful in print and place them on the Web, for each medium has its own characteristics. Therefore, the design of the company's web site has a companywide impact. For example, if a customer on the web can verify that an item is available, the chances of closing the sale are increased. More so, if a customer can find out the expected delivery date of the product and the means, the chances of a sale are increased even more. In this scenario, front-and back-end operations touch, and delivering the products is still key to success. Nonetheless, customers still want speed, convenience, quality, and good service. In this regard, the web is no different from conventional stores and catalogues. Customers ultimately will cast their votes for the companies that provide the best product experience whether they see the product on the web or can touch it in stores (Bateman \& Snell, 2011).

Farooq (2001) reported that the enormous flexibility of the internet has made possible what is popularly called e-commerce, which has made inroads in the traditional method of business management. In fact, under the impact of the web, businesses are seeing as realignment of the traditional relationships among producers, wholesalers, distributors, and retailers. All facts of business tradition with which we are accustomed in physical environment can now be executed over the internal including online advertising, ordering, publishing banking, investment, auction and professional services (Lawal \& Ogbu, 2015). To reduce printing costs and make documents widely available companies are digitizing information. In some instances, they are posting it on the Web. Different people residing in distant places can view the same information. Still, digitizing information is not without its obstacles. Not all people have the same hardware and software used for viewing and printing out information. In addition, miscommunications can occur that otherwise might not if all employees were working under one roof. Companies must take these 
circumstances into account when deciding how to make use of the web, for the decisions that affect each of the company's functioning units.

E-commerce, however, has not been widely tapped into in Nigeria. Many Nigerians still treat its benefits with deep scepticism. First, posting certain kinds of information does not usually cause problems. For example, providing company addresses, phone numbers, hours of operation, and the like, is more economically done on the web or over the Internet. However, supplying other types of information, however, might not be as free of repercussions as in the preceding examples. Depending on whether the company is a business-to-business or a business-to-consumer operation, buyers will want product information, forms and terms of payment, special sales, return policies, status of an order, shipping rates and turnaround, possibility of changing a current order, tracking information, etc. providing and maintaining only one piece of this information, for example, change in an order, affects at least three departments: accounting, marketing and distribution. Each department supplying in information must be aware of the consequences of making the information available and have a mechanism for handing changes otherwise the situation would have resulted to fear of inadequate security in online environment. Coordination becomes an issue as well. For example, charges to a creditcard account must not occur before the merchandise is shipped. Whether selling to another business or to consumers, online operation requires new networks. Other reasons why many Nigerian still treat e-commerce benefits with deep scepticism include high rate of illiteracy, high cost of internet, fear of risk and frequent power interruption. E-commerce in Nigeria covers three main types of transactions, e.g. business-to-business (B2B), businessto-consumer (B2C), and Business-to-government (B2G).

\section{E-commerce Development in Nigeria}

In view of the importance attached to e-commerce, the Federal Government of Nigeria through her various agencies came up with various institutional arrangement to sanitise the finance sector of the economy, check the tide of fraudulent practices in the country and to check the financial malpractice of banks. The following are some of the major efforts made by the Nigerian government to promote the development of e-commerce in Nigeria:

Legislative Efforts: The government of Nigeria instituted a number of regulatory measures to sanitize the finance sector of the economy, such as the Independent Corrupt Practices Commission (ICPC) Act of 1999; the national Drug Law Enforcement Agency (NDLEA) Act of 1989; the Money laundering Act of 1995; the Failed Bank (recovery of debt and financial 
malpractice of banks) Act of 1994. They were set up to check the tide of fraudulent practices in the country. The other bodies instituted to check the menace of fraud are the National Cyber Crime Working Group (NCWG), and the Economic and Financial Crimes Commission (EFCC) among others (Lawal \& Ogbu, 2015). As part of the efforts to curb the tide of fraudulent practices in the financial institutions in Nigeria, a Nigerian (IT) solutions provider is already in partnership with SAS of South Africa to introduce an anti-money laundering solution for the financial service institutions (Chibueze, 2006) cited in Lawal and Ogbu (2015).

On-Going ICT Projects: These include the mobile internet Units (MIUs) and the WIN project. The mobile internet Units include businesses equipped with ICT facilities such as PCs, VSATs and peripheral devices which are used to carry ICT education to rural areas. The WIN project is a project tagged "Wire Nigeria". It was intended to provide ICT infrastructure to all the nooks and crannies of the country. The project includes the provision of VSATs to the 774 local governments areas in the country, and the installation of the necessary infrastructures particularly, fibre optic backbone across the nation (Lawal \& Ogbu, 2015).

National Policy for Information: The policy formulated in the year 2000 is responsible for the monumental development in the sector. The vision is to make Nigeria an IT capable country in Africa and a key player in the information society. Its primary mission is to "Use IT" for education; creation of wealth; poverty eradication; job creation; governance; health; agriculture etc. (Ajayi, 2005) cited in Lawal and Ogbu (2015). However, in the year 2006, Nigeria was reported as the fastest growing telecoms nation in Africa. According to Iroegbu (2013), e-commerce is growing very rapidly, an estimated volume of about N75 billion was done by e-commerce in Nigeria as at 2012 and if that is current, in another four or five years we will be looking at N160 billion.

\section{Growth of E-commerce in Nigeria}

Internet World Start (2014) reported that with a population of over 160 million and an already thriving e-commerce market, Nigeria is becoming a game changer in African e-commerce and that Nigeria's ICT sector has grown exponentially over the past five years, with the recent implementation of its five year National Broadband plan which will see Nigeria's broadband internet penetration increasing by $80 \%$ by the end of 2018, the country is likely to surpass South Africa's e-commerce market. At present, Nigeria's e-commerce industry is significantly growing after the coming of jumia.com in 2001. There are now numerous online retailers such konga.com; taafoo.com.ng; kamdora.com.ng; kaymu.com.ng; cheki. 
com.ng; sunglasses.com.ng; ladiesshowwarehouse.com.ng; mystor.com. ng; olx.com.ng; nutrotechnologies.con.ng; tradestable.com.ng; dealdey. com.ng; oyoyo.com.ng and the likes. According to the Internet World Start (2014), there were 200000 internet users in Nigeria in the year 2000. By 31 December, 2016, the internet users stood at 86219965 representing $46.1 \%$ of the total population. This shows an increasing number of users of the internet in Nigeria from $0.1 \%$ in 2000 to $46.1 \%$ of its population in 2016 as shown in the table below.

Table 1. Internet penetration in different countries in 2016

\begin{tabular}{|c|c|c|}
\hline Country & Internet Users (2016) & Penetration \\
\hline China & $721,434,547$ & $52.2 \%$ \\
\hline India & $462,124,989$ & $34.8 \%$ \\
\hline U.S & $286.942,362$ & $88.5 \%$ \\
\hline Brazil & $139,111,185$ & $66.4 \%$ \\
\hline Japan & $115,111,595$ & $91.1 \%$ \\
\hline Russia & $102,258,256$ & $71.3 \%$ \\
\hline Nigeria & $86,219,965$ & $46.1 \%$ \\
\hline Germany & $71,016,605$ & $88.0 \%$ \\
\hline U.K & $60,273,385$ & $92.6 \%$ \\
\hline Mexico & $58,016,997$ & $45.1 \%$ \\
\hline
\end{tabular}

Source: Chaithralami and Shruthi (2016)

The above table reveals that e-commerce in Nigeria is fast rising in Africa.

According to Internet World Starts (2017) there were 200000 internet users less than $1 \%$ of the Nation population (precise $0.1 \%$ ). In the year 2006, the number has grown to 5000000 (again just 3.1\% of the national population). In 2009, the figure went above double as 23982200 million people used internet in Nigeria. By December 2011, the number of internet users in Nigeria has grown to 45039911 representing 26.5\% of the country's population. By June 20, 2012, the number of internet users has risen to 48366711 which is 28.45 of the total population. By December 31, 2013, the internet users have risen to 67319186 representing 38.0\%. By December 31, 2015, the internet users increased to 92699924 representing $51.1 \%$ of the total population. By 26 June, 2017, the internet users stood at 96598757 representing $53.0 \%$ of the total population. This shows an increasing number of users of the internet in Nigeria from $0.1 \%$ in 2000 to $53.0 \%$ of the total population in 2017 as shows in table 2 below. 
Table 2. Internet Usage and Population Growth

\begin{tabular}{|c|c|c|c|c|}
\hline Year & Users & Population & $\%$ Pen. & Usage Source \\
\hline 2000 & 200000 & 142895600 & $0.1 \%$ & ITU \\
\hline 2006 & 5000000 & 159404137 & $3.1 \%$ & ITU \\
\hline 2009 & 23982200 & 149229090 & $16.1 \%$ & ITU \\
\hline 2011 & 45039711 & 155215573 & $26.5 \%$ & ITU \\
\hline 2012 & 48366179 & 170123740 & $28.4 \%$ & ITU \\
\hline 2013 & 67319186 & 177155754 & $38.0 \%$ & ITU \\
\hline 2015 & 92699924 & 181562056 & $51.1 \%$ & IWS \\
\hline 2017 & 93598757 & 184611247 & $53.0 \%$ & NCC \\
\hline
\end{tabular}

Source: ITU, IWS and NCC

More so, one aspect of e-commerce that has been widely accepted by the Nigerian population is the of e-banking and payment systems. At present, over $90 \%$ of Nigerian banks offer online, real-time banking services which allows customers to perform banking transactions from the convenience of their home or offices. The growth of credit/debit cards and ATMs (Automated teller machines) is proof of the country's rapidly developing e-commerce. Nigerians can now pay, withdraw or transfer funds anywhere in the country with the introduction of master card, Visa Card, Inter Swish, and e-transact (Ovia, 2007). However, consumer attitudes to e-commerce goes a long way in determining its survival and sustainability in developing markets and economy at large. Andre Groves (1983) stated that "In the future, all companies will be internet companies". In this framework, e-commerce symbolises the future and the future is here now. In the words of Kinder (2002), business will be e-commerce or no business at all. E-commerce strategy should be crafted around mobile platforms in order to achieve a goal mileage in the interim and a substantial level of market penetration in Nigeria (Ibrahim \& Abubakar, 2015).

\section{ICT Impact on the Growth of E-commerce in Nigeria}

It is important to state the importance of the ICT as it is the base of the e-commerce platforms. This is due to the fact that ICT or web has been a very useful tool in breaking through different nations and transactions can be done at almost any time irrespective of the various time zones that exist around the world. Therefore, ICT is one of the most crucial determining factors for the growth of e-commerce. The growth of e-commerce requires reliable access to modern technologies which is typically lacking in most developing economies. Kuliya (2015) affirms that 
ICT's relevance in the growth of e-commerce cannot be overemphasised because of mobile phones, computers, internet, and so on for us to use in our everyday life. The impact of ICT on the growth of e-commerce in Nigeria are:

1) ICT has brought a major paradigm shift in e-commerce in the entire world. It has made access to buying and selling of goods and services less complex and difficult.

2) ICT has made e-commerce to become the cheapest means of doing business in Nigeria since costs of trading are lower and there is savings on staff, premises and storage of goods and services.

3) ICT has helped businesses in Nigeria in cost savings by using e.g. VOLP instead of normal telephone, e-mail instead of post, video conferencing instead of travelling to meetings, e-commerce web sites instead of sales catalogues.

4) ICT enhance efficiency in e-commerce by providing access to new markets or services which in turn create new favourable condition for income generation that can lessen poverty, improve governance, improve per capital income, and reduces unemployment in Nigeria.

5) Through the help of ICT, e-commerce can reduce the delivery time by using efficient integrated computer systems which allows buyers to browse a wider selection of Goods and services from their home.

6) ICT increases percentage of local content in products and services, utilization of local capacity, increases percentage of domestic value-add and increased opportunities for job creation.

It is however, noteworthy to state that e-commerce activity in Nigeria is steadily growing as a result of vast improvements in telecommunication services.

\section{Advantages and disadvantages of E-commerce}

E - Commerce is increasingly viewed as a 'win-win' strategy for businesses and consumers. The following are advantages and disadvantages of e-commerce.

\section{Advantages for Businesses}

- Increased potential market share,

- Access to customers data,

- Low-cost advertising,

- Able to process a higher number of orders,

- Low barriers to entries,

- Easy to showcase bestsellers. 


\section{Advantages for Consumers}

- Reduced prices,

- Less invasive experience,

- Access to global marketplace,

- Easy to scale business quickly,

- 24/7 access.

\section{Disadvantages for Businesses}

- Hardware and software

- Is highly competitive,

- Maintenance of website,

- Establishing cost,

- Training and maintenance of competent personnel,

- Website stickiness and customer loyalty,

- Insufficient telecommunication facilities,

- Erratic electric supply.

\section{Disadvantages for Consumers}

- There is no guarantee of product quality,

- Unable to examine products personally,

- Online purchasing security issue,

- Network reliability issue,

- Exposure to various forms of cyber crimes.

\section{Benefits of E-Commerce}

The E-commerce industry had continued to receive a boost in Nigeria. The uptake of e-commerce is influenced by its potential to create business value and by awareness of its participants of the potential benefits (Salnoske, 1997). A major reason for most companies, irrespective of size, to participate in business is to extract some benefits from it. E-commerce is no different. The benefits of e-commerce identified from the current literature are classified in two main categories- tangible and intangible. Table 3 presents the key benefits as described in the literature. 
Table 3. Key benefits of E-commerce

\begin{tabular}{|c|c|c|}
\hline & Tangible Benefits & Research/Literature \\
\hline 1. & Business efficiency & $\begin{array}{l}\text { (Riggins, 1999; Fraser, Fraser \& McDonald, } \\
\text { 2000; Lee, 2001) }\end{array}$ \\
\hline 2. & $\begin{array}{l}\text { Increased automation of } \\
\text { processes }\end{array}$ & (Fraser et al., 2000; Dan, Dias \& Kearney, 2001) \\
\hline 3 , & $\begin{array}{l}\text { Transformation of traditional } \\
\text { market chain }\end{array}$ & $\begin{array}{l}\text { (Fraser et al., 2000; Kuzic, Fisher \& Scollary, } \\
\text { 2002) }\end{array}$ \\
\hline 4 , & $\begin{array}{l}\text { Retained and expanded } \\
\text { customer base }\end{array}$ & $\begin{array}{l}\text { (Fraser et al., 2000; Tuban, lee, King \& Chung, } \\
\text { 2000; Rahul, Biju \& Abratiam, 2001) }\end{array}$ \\
\hline 5. & Reduced operation costs & $\begin{array}{l}\text { (Kare-silver, 1998; Fergusson, 1999; kent \& Lee, } \\
\text { 1999; Grover \& Ramanlal, 2001) }\end{array}$ \\
\hline \multirow[t]{2}{*}{6.} & Acquisition of a niche market & $\begin{array}{l}\text { (Riggins, 1999; Rahul et al., 2001; Kuzic et al., } \\
\text { 2002) }\end{array}$ \\
\hline & \multicolumn{2}{|l|}{ Intangible Benefits } \\
\hline 7. & $\begin{array}{l}\text { Enhancing well-being and } \\
\text { education of customers }\end{array}$ & (Whinston, Stabl \& Soon-Yong, 1997; Lee, 2001) \\
\hline 8. & Customer loyalty & $\begin{array}{l}\text { (Coulson, 1999; Hoffman, Novak \& Perlata, } \\
\text { 1999; Lee, 2001) }\end{array}$ \\
\hline 9. & Competitive advantage & $\begin{array}{l}\text { (Kare-silver, 1998; Hoffman et al., 1999; } \\
\text { Kalakota, Oliva \& Donath, 1999; Straub, 2000) }\end{array}$ \\
\hline 10. & Convenient shopping & Winner, 1997; Honnon, 1998. Kuzic et al., 2002) \\
\hline
\end{tabular}

In addition, the appearance of e-commerce has transformed the traditional means of shopping and doing business, and this swift acceptance had certainly brought with it more e-commerce business models in Nigeria, and has introduced more competition. The coming of e-commerce has brought opportunities for the future generation of creative young individuals in the country and these individuals will in turn contribute to nation's growth technological. Also, e-commerce enhances the speed and accuracy with which businessmen can share information and this reduces costs of online transaction in Nigeria. Lastly, e-commerce enables the customers to shop at the comfort of their home, office and anyplace where there is internet connectivity (Kuliya, 2015).

\section{Challenges of E-commerce}

E-commerce challenges identified from the literature are classified as technological, managerial, and business related and are summarised and presented in Table 4 below. 
Table 4. E-commerce challenges identified from the literature

\begin{tabular}{|c|c|c|}
\hline & Challenges & Research/literature \\
\hline & \multicolumn{2}{|l|}{ Technological Challenges } \\
\hline 1. & Security & $\begin{array}{l}\text { (Alexander, 1998; Czerniawska \& Potter, 1998: } \\
\text { Koved et al., 2001) }\end{array}$ \\
\hline 2. & Web site issues & $\begin{array}{l}\text { (Watson, Berthon, Pitt \& Zinhan, 1999; Zhang \& } \\
\text { Von-Dran, 2000; Lee, 2001; Kuzic et al. 2002) }\end{array}$ \\
\hline \multirow[t]{2}{*}{3.} & $\begin{array}{l}\text { Technology issues including } \\
\text { costs, software and } \\
\text { infrastructure }\end{array}$ & $\begin{array}{l}\text { (Abeyesekera, Criscuolo, Barreto \& Gallapher, } \\
\text { 1999; Hoffman et al., 1999; Rahul et al., 2001; } \\
\text { Kuzic et al. 2002) }\end{array}$ \\
\hline & \multicolumn{2}{|l|}{ Managerial Challenges } \\
\hline 4. & $\begin{array}{l}\text { People and organizational } \\
\text { issues }\end{array}$ & $\begin{array}{l}\text { (Hoffman et al., 1999; Feeny, 2000; Kuzic et al., } \\
\text { 2002) }\end{array}$ \\
\hline \multirow[t]{2}{*}{5.} & $\begin{array}{l}\text { Obtaining senior management } \\
\text { backing }\end{array}$ & (Feeny 2000, Kuzic et al., 2002) \\
\hline & \multicolumn{2}{|l|}{ Business Challenges } \\
\hline 6. & Customer service & (Whinston et al., 1997; Alter, 1999: Lee, 2001) \\
\hline 7. & Customers' old habits & $\begin{array}{l}\text { (Hoffman et al., 1999; Schwartz, 1999; Kuzic } \\
\text { et al., 2002) }\end{array}$ \\
\hline 8. & Legal issues & $\begin{array}{l}\text { (Lawrence et al., 1998; Hoffman et al., 1999; } \\
\text { De-Souza \& Von Wiese, 2000; Kuzic et al., 2002) }\end{array}$ \\
\hline
\end{tabular}

E-commerce in Nigeria context has numerous challenges and these challenges have impacted negatively to the growth of the economy. Some of these challenges identified in the literature are summarised and presented in table 5 below.

Table 5. E-commerce challenges in Nigeria

\begin{tabular}{|r|l|l|}
\hline & \multicolumn{1}{|c|}{ Challenges } & \multicolumn{1}{c|}{ Research/ Literature } \\
\hline 1. & $\begin{array}{l}\text { Power outage and frequent } \\
\text { power interruption }\end{array}$ & $\begin{array}{l}\text { (Larossi, Mousley \& Radwan, 2009; Kuliya, 2015; } \\
\text { Lawal \& Ogbu, 2015; Okifo \& Igbunu, 2015) }\end{array}$ \\
\hline 2. & Fear of inadequate security & $\begin{array}{l}\text { (Atanbasi, 2010; Kuliya, 2015; Lawal \& Ogbu, } \\
\text { 2015) }\end{array}$ \\
\hline 3. & High rate of poverty & (Kunliya, 2015) \\
\hline 4. & High cost of accessing the web & $\begin{array}{l}\text { (Kuliya, 2015; Lawal \& Ogbu, 2015; Okifo \& } \\
\text { Igbunu, 2015) }\end{array}$ \\
\hline 5. & Lack of trust in web retailers & (Ayo et al., 2011) \\
\hline 6. & Lack of adequate infrastructure & (Okifo \& Igbunu, 2015) \\
\hline 7. & $\begin{array}{l}\text { Insufficient telecommunication } \\
\text { facilities }\end{array}$ & $\begin{array}{l}\text { (Ayo, Ekong, Fatudimu \& Adebiyi, 2007; Ayo et al. } \\
\text { 2011); Lawal \& Ogbu, 2015; Olusoji, Ogunkoya \& } \\
\text { Elumah, 2015) }\end{array}$ \\
\hline
\end{tabular}




\begin{tabular}{|r|l|l|}
\hline & \multicolumn{1}{|c|}{ Challenges } & \multicolumn{1}{c|}{ Research/ Literature } \\
\hline 8. & Unreliable last-mile delivery & (Kuliya, 2015; Lawal \& Ogbu, 2015) \\
\hline 9. & High rate of illiteracy & (Okifo \& Igbunu, 2015) \\
\hline 10. & Lack of seriousness by banks & (Ayo et al., 2011; Okifo \& Igbunu, 2015) \\
\hline 11. & $\begin{array}{l}\text { Lack of privacy and } \\
\text { confidentiality }\end{array}$ & $\begin{array}{l}\text { (Ayo, 2006; Adeyeye, 2008; Adeshina \& Ayo, } \\
\text { 2010; Lawal \& Ogbu, 2015) }\end{array}$ \\
\hline 12. & Network reliability issues & (Ayo, 2006; Lawal \& Ogbu, 2015) \\
\hline 13. & $\begin{array}{l}\text { Authenticity and credit card } \\
\text { threat }\end{array}$ & $\begin{array}{l}\text { (Ayo, 2006; Adeshina \& Ayo, 2010; Ayo et al., } \\
\text { 2011; Yaqub, Bello, Adenuga \& Ogbundeji, 2013) }\end{array}$ \\
\hline
\end{tabular}

From the above table, it is obvious that internet penetration is still abysmally low and is one of the major threats to e-commerce implementation in the country. However, companies in Nigeria forge ahead nonetheless in this burgeoning technology, realising that the potential advantages are well worth the temporary discomforts.

\section{Methodology}

The survey research method was used in this study. The survey method is used to obtain information from the respondents because it is cost effective and not time consuming. The study employs a questionnaire as the major instrument used to gathered data from respondents. The questionnaire was divided into two sections. The first section consists of demographic profile, internet usage, and online shopping activities of the respondents. The second section consists of the benefits of e-commerce and the challenges of e-commerce that inhibit its successful operation. The data gathered from the questionnaire responses are ordinal and presented on a Likert Scale. The Likert scale is commonly used in business research, because it allows participants to respond with degrees of agreement or disagreement. Participants were asked to rate their encountered benefits and challenges respectively. The study covers six (6) different cities: Edo, Delta, Lagos, Port Harcourt, Abuja and Abia. The simple random sampling technique was used to select the target population. There were 1200 questionnaires randomly administered within six (6) months, 917 were received, and 78 of them were incomplete. The remaining 839 valid and completed questionnaire were used for the quantitative analysis representing $69.9 \%$ response rate.

The reliability of the instrument was established through a trial test conducted on 50 respondents who also took part in the study. Cronbach Alpha method was used to establish the internal consistency of the instrument. The result yields a coefficient of $0.83 \%$, which satisfied the general recommended level of 0.70 for the research indicators (Cronbach, 1951) 
of the study. The collected data was entered in Microsoft excel 2007 and analysis were done through the aid of Statistical Package for Social Science (SPSS) version 21. The sign test was used to compare the number of positive and negative differences between scores allocated to the same or matched samples. The sign test was computed with alpha 0.05 .

\section{Analysis Results}

From Table 6 it can be concluded that majority of the respondents are male representing $53.0 \%$ while $47.0 \%$ were female. $85.0 \%$ of the respondents were of ages between 21 to 50 years. $38.9 \%$ of the respondents are working in the educational field, $16.4 \%$ are involved in one form of trading, $15.8 \%$ are in manufacturing industry and $15.4 \%$ are civil servants. $68.2 \%$ of the respondents holds an NCE, OND, HND, B.Sc. and Post graduate certificate. This revealed that above 68 percent of the respondents are educated and potential users of e-commerce facilities.

Table 6. Demographic Profile

\begin{tabular}{|l|c|c|}
\hline \multicolumn{1}{|c|}{ Variable } & Frequency & Parentage \\
\hline Gender & & \\
Male & 441 & 53.0 \\
Female & 398 & 47.0 \\
Total & 839 & 100 \\
\hline Age & & \\
$<20$ & 23 & 2.7 \\
$21-30$ & 101 & 12.0 \\
$31-40$ & 363 & 43.3 \\
41-50 & 249 & 29.7 \\
51-60 & 76 & 9.1 \\
60+ & 27 & 3.2 \\
Total & 839 & 100 \\
\hline Occupation & & \\
Trading & 138 & 16.4 \\
IT & 61 & 7.3 \\
Civil servant & 129 & 15.4 \\
Education & 326 & 38.9 \\
Manufacturing & 133 & 15.8 \\
Others & 52 & 6.2 \\
Total & 839 & 100 \\
\hline Education & & \\
Primary & 68 & 8.1 \\
Secondary & 103 & 12.3 \\
Colleges of education/HOD & 147 & 17.3 \\
B.Sc./HND & 274 & 32.7 \\
Post-graduate & 151 & 18.0 \\
Others & 96 & 11.4 \\
Total & 839 & 100 \\
\hline
\end{tabular}


From Table 7, the internet usage of respondents revealed that $43.6 \%$ had fair access to internet, $33.5 \%$ access very often and $22.9 \%$ always had access to the internet. Public café represented $28.3 \%$ of the internet access of the respondents, $30.5 \%$ accessed the internet while in the office and $41.2 \%$ had private means of connecting to the internet. Online shopping behaviour of respondents indicated that only $42.3 \%$ had procured goods online. $66.7 \%$ of the respondents visited online shops in a month while $33.3 \%$ of the respondent had never visited any online shop. ATM is the dominant payment instrument among respondent representing $28.7 \%$ of the respondents.

Table 7. Internet Usage and Online Shopping Activities

\begin{tabular}{|c|c|c|}
\hline Variable & Frequency & Percentage \\
\hline $\begin{array}{l}\text { Frequency of Internet access } \\
\text { Fairly often } \\
\text { Very often } \\
\text { Always } \\
\text { Total }\end{array}$ & $\begin{array}{l}366 \\
281 \\
192 \\
839\end{array}$ & $\begin{array}{l}43.6 \\
33.5 \\
22.9 \\
100 \\
\end{array}$ \\
\hline $\begin{array}{l}\text { Mode of Internet access } \\
\text { Public café } \\
\text { Office } \\
\text { Personal } \\
\text { Total }\end{array}$ & $\begin{array}{l}237 \\
256 \\
346 \\
839\end{array}$ & $\begin{array}{c}28 \\
30.5 \\
41.2 \\
100\end{array}$ \\
\hline $\begin{array}{l}\text { Have you procured good online? } \\
\text { Yes } \\
\text { No } \\
\text { Total }\end{array}$ & $\begin{array}{l}355 \\
484 \\
839 \\
\end{array}$ & $\begin{array}{l}42.3 \\
57.7 \\
100\end{array}$ \\
\hline $\begin{array}{l}\text { Using internet for shopping } \\
\text { activities } \\
\text { Once a year } \\
\text { Two or three times a year } \\
\text { Monthly } \\
\text { Daily } \\
\text { Not at all } \\
\text { Total }\end{array}$ & $\begin{array}{c}112 \\
127 \\
237 \\
94 \\
269 \\
839\end{array}$ & $\begin{array}{l}13.3 \\
15.1 \\
28.2 \\
11.2 \\
32.2 \\
100\end{array}$ \\
\hline $\begin{array}{l}\text { Online shops visited in a month } \\
1-5 \\
6-10 \\
11-20 \\
\text { Over } 20 \\
\text { None } \\
\text { Total }\end{array}$ & $\begin{array}{l}213 \\
128 \\
111 \\
108 \\
279 \\
839\end{array}$ & $\begin{array}{c}25.4 \\
15.3 \\
13.3 \\
12.9 \\
33.3 \\
100 \\
\end{array}$ \\
\hline $\begin{array}{l}\text { Mode of payment } \\
\text { Master card } \\
\text { Visa card } \\
\text { ATM } \\
\text { Western union } \\
\text { Cash on delivery } \\
\text { Others } \\
\text { Total }\end{array}$ & $\begin{array}{c}191 \\
143 \\
241 \\
86 \\
135 \\
43 \\
839\end{array}$ & $\begin{array}{c}22.8 \\
17.0 \\
28.7 \\
10.3 \\
16.1 \\
5.1 \\
100\end{array}$ \\
\hline
\end{tabular}


Table 8 indicated that the most achieved benefits included increased sales, competitive advantage, customer loyalty, increased automation of processes, extended application of new technology, better knowledge management, and enhanced well-being and education of customer. The results of the sign test indicated that four benefits that were not correctly anticipated including competitive advantage, reduced operation cost, acquisition of a niche market and reduce inventories.

Table 8. Benefits of E-commerce in Nigeria

\begin{tabular}{|c|c|c|c|c|}
\hline No & Benefits & Frequency & Percentage & Sign. T. Signif. \\
\hline 1. & Increase sales & 57 & 6.8 & 0.58 \\
\hline 2. & Competitive advantage & 59 & 7.0 & $0.000^{\text {米 }}$ \\
\hline 3. & Reduced operation costs & 49 & 5.8 & $0.015^{* * * * *}$ \\
\hline 4. & Customer loyalty & 64 & 7.6 & 0.073 \\
\hline 5. & Business efficiency & 55 & 6.6 & 0.63 \\
\hline 6. & Enhanced skills of employees & 56 & 6.7 & 0.107 \\
\hline 7. & Increased automation processes & 61 & 7.3 & 0.107 \\
\hline 8. & Retained and expanded customer base & 53 & 6.3 & 1.000 \\
\hline 9. & Improved image & 49 & 5.8 & 0.125 \\
\hline 10. & Acquisition of a niche market & 56 & 6.7 & 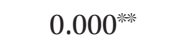 \\
\hline 11. & $\begin{array}{l}\text { Secure electronic commerce } \\
\text { environment }\end{array}$ & 47 & 5.6 & 0.581 \\
\hline 12. & Reduced inventories & 53 & 6.3 & $0.013^{* * * *}$ \\
\hline 13. & Extended application of new technology & 57 & 6.8 & 0.508 \\
\hline 14. & Better knowledge management & 59 & 7.0 & 0.772 \\
\hline 15. & $\begin{array}{l}\text { Enhanced well-being and education of } \\
\text { customers }\end{array}$ & 64 & 7.6 & 0.668 \\
\hline & Total & 839 & 100 & \\
\hline
\end{tabular}

Table 9 indicated that the most frequent challenges of e-commerce encountered in Nigeria include power outages and frequent power interruption, insecurity, technology cost, lack of trust, software compatibility, and acquiring IT skilled personnel. The results of the Sign Test indicated that the challenges of high rate of poverty, high rate of illiteracy, acquiring IT skilled personnel and customer service were not correctly anticipated. 
Table 9. Challenges of E-commerce in Nigeria

\begin{tabular}{|c|c|c|c|c|}
\hline No & Challenges & Frequency & Percentage & Sign. T.Signif. \\
\hline 1. & $\begin{array}{l}\text { Power outage and frequent power } \\
\text { interruption }\end{array}$ & 52 & 6.2 & 1.375 \\
\hline 2. & Insecurity & 65 & 7.7 & 1.000 \\
\hline 3. & High rate of poverty & 31 & 3.7 & $0.011^{\text {米米 }}$ \\
\hline 4. & High rate of illiteracy & 47 & 5.6 & $0.000^{\text {米 }}$ \\
\hline 5. & Technology cost & 51 & 6.0 & 0.58 \\
\hline 6. & Lack of e-commerce infrastructure & 30 & 3.6 & 1.774 \\
\hline 7. & Reliable technology vendor & 31 & 3.7 & 0.143 \\
\hline 8. & Making business known to users & 24 & 2.9 & 0.815 \\
\hline 9. & Lack of seriousness by banks & 17 & 2.0 & 0.109 \\
\hline 10. & Authenticity and credit card threat & 34 & 4.1 & 1.000 \\
\hline 11. & Lack of privacy and confidentiality & 34 & 4.1 & 0.125 \\
\hline 12. & Lack of trust in web retailers & 52 & 6.2 & 0.813 \\
\hline 13. & Acquiring IT skilled personnel & 56 & 6.7 & $0.000^{\text {拳 }}$ \\
\hline 14. & Unreliable last mile delivery & 22 & 2.6 & 0.092 \\
\hline 15. & Managing change & 33 & 3.9 & 0.0625 \\
\hline 16. & Obtaining senior management support & 21 & 2.5 & 0.188 \\
\hline 17. & Reaching customers in rural areas & 40 & 4.8 & 0.092 \\
\hline 18. & Current e-commerce legislation & 18 & 2.1 & 0.096 \\
\hline 19. & Dealing with intermediaries & 30 & 3.6 & 0.518 \\
\hline 20. & Software compatibility & 52 & 6.2 & 0.180 \\
\hline 21. & Internet service provider reliability & 33 & 3.9 & 0.625 \\
\hline 22. & Web site issues & 21 & 2.5 & 0.774 \\
\hline 23. & $\begin{array}{l}\text { Employee resistance towards } \\
\text { e-commerce }\end{array}$ & 24 & 2.9 & 0.549 \\
\hline \multirow[t]{2}{*}{24.} & Customer service & 21 & 2.5 & $0.021^{\text {****** }}$ \\
\hline & Total & 839 & 100 & \\
\hline
\end{tabular}

\section{Discussion of Results}

E-commerce has unarguably made our lives easier. E-commerce as a new way of doing business has significant opportunities. Despite the numerous benefits that e-commerce brings to the nation, individuals and banks, it also 
has its challenges. However, e-commerce is fast gathering momentum and becoming a reality in Nigeria as in other parts of the world. To maximise the potential of e-commerce, businesses or e-commerce industries in the country must be aware of the benefits and challenges including success factors of trading electronically. The main findings of the research presented in this study are:

1) Above $68 \%$ of the respondents are educated and potential users of e-commerce facilities in Nigeria.

2) ATM is the dominant payment instrument among respondents.

3) The major benefits of e-commerce in Nigeria are increased sales, completive advantage, customer loyalty, increased automation of processes, extended application of new technology, better knowledge management, and enhanced well-being and education of customers.

4) The key challenges identified in the adoption of e-commerce in Nigeria are power outages and frequent power interruption, insecurity, technology costs, lack of trust, software capability, and acquisition of IT skilled personnel.

5) The major benefits of e-commerce adoption not correctly anticipated are competitive advantage, reduced operation costs, acquisition of a niche market, and reduced inventories.

6) Participating respondents correctly estimated the vast majority of challenges of e-commerce that discourage most people from fully adopting and using e-commerce, thereby hindering the development of e-commerce in Nigeria. High rate of poverty, high rate of illiteracy, acquisition of IT skilled personnel, and customer service was, however, four significant challenges that was not correctly anticipated.

\section{Policy Recommendations}

a. Government and private organisations should systematically expand the necessary infrastructure by promoting the development of necessary technologies, expanding high speed information network and recruiting IT skilled personnel as this will promote the growth of e-commerce in the country.

b. Applicable regulations including those for electronic approval processes, consumer protection, e-commerce legal framework should be stabilised and standardised in order to attract and increase the confidence of e-commerce users.

c. The government of Nigeria and private organisations should invest in training, adequate publicity and other enlightenment programs that are very vital to attitudinal changes of consumers to e-commerce transaction with emphasis on e-shopping, e-banking and e-business. 
d. E-commerce strategy should be crafted around mobile platforms in order to achieve a good mile- age in the interim and a substantial level of market penetration in Nigeria as this will stimulate interest of business on e-commerce and gives consumers more market power and companies unlimited access to customers across the globe.

e. The government of Nigeria should provide the much needed leadership, support for e-commerce, and secured the internet from online fraudsters.

f. In order for e-commerce industries in the country to thrift and raise the country's GDP, there should be steady power supply as this will enhance economic activities in the country.

g. In order to maximise value from e-commerce in Nigeria, businesses or e-commerce industries should identify and evaluate critical success factors such as secure transaction, top management support, functional and user-friendly web site, partnership with technology providers, regular update of the content of the web site, partnership with service providers, active role of IT department in organisation, online tracking facilities, online personalised recommendations, web site listed on critical search engines, comprehensive e-commerce legislation, appropriate packaging, e-payment system, the use of new technology, integrating web site to all business processes, rapid delivery, adequate resources (finance \& people), appropriate organisation structure, more personalised customer service, and responsive and flexible to the market etc.

The authors are of the opinion that if the recommendations are adhered to, e-commerce in Nigeria would continue to improve economic efficiency, competitiveness, and social and economic development.

\section{Conclusion}

This study has identified benefits and challenges as they relate to e-commerce in Nigeria. A series of interviews, not discussed in this study, was conducted with online vendors in Nigeria. It was revealed that some customers are concerned about perceived ease of use and insufficient information on the e-commerce site. This is more a perception than a real problem. However, perception motivates people's actions, preventing some from making the leap into cyber shopping. Therefore, adequate information should be made available on the e-commerce web site as this will reduce perceive risk on intentions to use e-commerce. More so, the success of e-commerce largely depends on ease of use, security, consumer preferences, acceptability, industry, agreement, and authorisation. 


\section{REFERENCES}

Abeyesekera, A., Criseuolo, C., Barreto, E., \& Gallagher, P. (1999). "Partners speak out: Views on e-commerce". International trade Forum, 2: pp. 23-25.

Adeshina, A. A., \& Ayo, C. K. (2010). "An empirical investigation of the level of users' acceptance of e-baking in Nigeria”. Journal of Internet Banking and Commerce, 15(1): pp. $1-13$.

Adeyeye, M. O. (2008). "E-commerce, business methods and evaluation of payment methods in Nigeria”. Electronic Journal Information Systems Evaluation, 11(1): pp. 1-6.

Ajyi, A. (2005) "Improving the response time on online buyers in Nigeria: The way forward”. Journal of Internet Banking and Commerce, 13(1): pp. 1-10.

Alexander, R. (1998). "E-commerce security: An alternative business model". Journal of Retail Banking Service, 2(6): pp. 1-12.

Alter, S. (1999). "Shopping. Com: when e-commerce isn't a bargain”. Communication of the Association for Information Systems, 2: pp. 22-31.

Andam, Z. R. B. (2003). "An introduction to electronic commerce and SMEs: E-commerce in three Philippine cities”. Retrieve from www.electronic-e-commerce/threephiloppine cities.net.

Anup, K. G. (1997). "Securing e-commerce: A systemic approach". Journal of Internet Banking and Commerce, 2(4): pp. 7-15.

Atabansi, L.A. (2010). “We can grow our technology”. Retrieved from en.wikipedia.org/ wiki/electronic payment.

Ayo, A. O. (2006). "The prospects of e-commerce implementation in Nigeria". Journal of Internet Banking and Commerce, 11(3): pp. 1-8.

Ayo, A. O. (2011). "Emergence of payment systems in the era of e-commerce in Nigeria: problems and prospects". Delta Business Education Journal, 1(6): pp. 64-72.

Ayo, C. K., Adewoye, J. O., \& Oni, A. A. (2011). "Business-to-consumer e-commerce in Nigeria: Prospects and challenges”. African Journal of Business Management, 5(13): pp. 5109-5117.

Ayo, C. K., Ekong, O. U., Fatudimu, T. I., \& Adebiyi, A. A. (2007). "M-commerce implementation in Nigeria: Trends and issues". Journal of Internet Banking and Commerce, 12(2): pp. 1-15.

Bateman, T., \& Snell, S. A. (2011). "Management: Leading \& collaborating in a competitive world”. New York: McGraw-Hill.

Chaithralaximi, T., \& Shruthi, N. (2016). "E-commerce in India: Opportunities and challenges". International Journal of Latest Trends in Engineering and Technology, (Special issue), pp. 505-510.

Czerniawska, F., \& Potter, G. (1998). "Business in a virtual world: Exploiting information for competitive advantage”. London: Macmillan Press.

Dan, A., Dias, D. M., Kearney, R., \& Lau, T. C. (2001). "Business-to- business integration with TPAML and a Business-to-business protocol framework”. IBM systems Journal, 40 (1): pp. 68-90.

De-Souza, N., \& Von-Wiese, I. (2000). "European Union: EU adopts directive on e-commerce”. International Financial Law Review, 19(7): pp. 61-62.

Farooq, A. (2001). "Electronic commerce: An Indian perspective”. International Journal of Law and Information Technology, 9(2): pp. 133-170. 
Feeny, D. (2000). "The CEO and the CIO in the information age: Moving to e-business". London: Random House.

Ferguson, M. (1999). "Revenue collection via the Internet: Transaction cost components". London: Collected Proceedings.

Fraser, J., Graser, N., \& McGonald, F. (2000). "The strategic challenge of electronic commerce”. Supply Chain Management, 5(1): pp. 7-14.

Grover, V., \& Ramanlal, P. (2000). "Playing the e-commerce game”. Business and Economic Review, 7(3): pp. 6-13.

Hannon, J. N. (1998). “The business of the internet”. USA: Course Technology ITP.

Hoffman, D., Novak, T., \& Perlata, M. (1999). "Building consumer trust online". Communications of the ACM, 42(4): pp. 80-85.

Ibrahim, I. A., \& Abubakar, M. (2015). "Technological adoption of e-commerce in Nigeria”. International Journal of Innovative research in Engineering \& Management, 2 (6): pp.1-7.

Internet world starts (2014). "Telecommunications, ICT and Internet Usage in Nigeria". Retrieve from http://www.internetwordstarts.com/af/ng.htm.

Internet World Starts (2017). "Telecommunication, ICT and Internet usage in Nigeria". Retrieved from http://www.internetworldstarts.com/af/ng.htm.

Iroegbu, K. (2013). "Broadband expansion driver of N150 Bn e-commerce industry: Nigeria communications week”. Retrieved from http://nigeriacommunicationsweek.com.ng/ telecomlbroadband-expansion-driven-of-n15obn-e-commerce-industry \#sthash.

Kalakota, R., Oliva, R., \& Donath, B. (1999). “Move over: E-commerce”. Marketing Management, 8(3): pp. 23-32.

Kare-Silver, M. (1998). "The electronic shopping revolution: strategies for retailers and manufacturers". London: Macmillan Press.

Kent, R., \& Lee, M. (1999). "Using the Internet for market research: A study of private trading on the internet”. Journal of Market Research Society, 41(4): pp. 317-342.

kinder, T. (2002). "Emerging e-commerce business models: An analysis of case studies from west Lothian, Scotland". European Journal of Innovation Management, 5(3): pp. 130-151.

Koved, L., Nadalin, A., Nagaratnam, N., Pistoia, M., \& Shrader, T. (2001) T. (2001). "Security challenges for enterprise java in an e-business environment". IBM Systems Journal, 40(1): pp. 130-152.

Kuliya, M. (2015). "The impact of information and communication technology in the growth of e-commerce in Nigeria: Challenges and prospects". International Journal of Scientific and Research Publications, 5(12): pp. 507-512.

Kuzic, J. Fisher, J., \& Scollary, A. (2002). "Electronic commerce benefits, challenges and success factors in the Australian banking and finance industry". ECIS, June 6-8: pp. 1607-1616.

Larossi, P., Muosley, E, \& Radwan, I. (2009). "An assessment of the investment climate in Nigeria”. USA: World Bank Publications.

Lawal, A. \& Ogbu, R. (2015). "E-commerce, problems and prospect in Nigeria". International Journal of Scientific Engineering and Applied Science, 1(3): pp. 230-236.

Lawrence, E., Corbitt, B., Tidwell, A., Fisher, J., \& Lawrence, J. (1998). “Internet commerce: Digital models for business". Brisbane: John Wiley \& Sons. 
Lee, C. S. (2001). "An analytical framework for evaluating e-commerce business models and strategies". Electronic Networking Applications and Policy, 11(4): pp. 349-359.

Mary-Anne, G. (1998). "E-commerce awareness programme for regional communities". Journal of Internet Banking and Commerce, 3(2): pp. 23-31.

Okifo, J., \& Igbunu, R. (2015). "Electronic payment system in Nigeria: Its economic benefits and challenges". Journal of Education and Practice, 6(16): pp. 56-62.

Olusoji, J. G., Ogunkoya, O.A., \& Elumah, L.O. (2015). "Risk and trust in online shopping: Experience from Nigeria”. International Journal of African and Asian Studies, 11: pp. 71-77.

Omobola, J. (2013). "E-commerce and ICT in Nigeria: An engine for job creation and economic growth”. Proceedings of E-commerce conference in Lagos, Nigeria. Organized by Jumia.com.

Ovia, F. (2007). "E-commerce in Nigeria: What the future holds". Retrieved from http// www.cipaco.org/spip.php?article 1158.

Rahal, D., Biju, M., \& Abraham, D. (2001) "Critical constructs for analysing e-business: Investment, user experience and revenue models". Logistics Information Management, 14(1/2): pp. 137-148.

Riggings, F. (1999). "A framework for identifying web-based electronic commerce opportunities". Journal of Organizational Computing and Electronic Commerce,9(4): pp. 297-310.

Salnoske, K. (1997). "Building trust in electronic commerce". Credit World, 85(6): pp. 9-11.

Schwartz, E. (1999). "Digital Darwinism: 7 breakthrough business strategies for surviving in the cutthroat web-economy". New York: Broadway Books.

Straub, A. (2000). "Net return: Purchasing and selling online”. Strategic Finance, 82(1): pp. 46-49.

Till, R. (1998). Transforming the way we do business in electronic commerce: Directors and opportunities for electronic business. London: Institute of Directors.

Turban, E., Lee, J., King, D, D., \& Chung, M. (2000). "Electronic commerce: A managerial perspective". New Jersey: Practice Hall International.

Watson, R., Berthon, P., Pitt, L., \& Zinhan, G. (1999). "Electronic commerce: A strategic perspective". USA: The Dryden Press.

Whinstone, A., Stabl, D., \& Soon-Yong, C. (1997). "The economics of electronic commerce". Indianapolis: Macmillan Press.

Winner, L. (1997). "The neverhood of internet commerce”. MIT Technology Review, 100 (6): pp. 31-36.

Yaqub, J. O., Bello, H. T., Adenuga, I. A., \& Ogundeji, M. O. (2013). “The cashless policy in Nigeria": Prospects and challenges. International Journal of Humanities and Social Science, 3(3): pp. 200-212.

Zhang, P., \& Von-Dran, G. (2000). "Satisfiers and dissatisfies: A two-factor model for website design and evaluation". Journal of the American Society of Information Science 51(14): pp. 1253-1268. 